Article

\title{
Assessment of the Economic and Environmental Impact of Double Glazed Façade Ventilation Systems in Mediterranean Climates
}

David Valentín ${ }^{1}$, Alfredo Guardo ${ }^{1, *}$, Eduard Egusquiza ${ }^{1}$, Carme Valero ${ }^{1}$ and Pere Alavedra ${ }^{2}$

1 Center for Industrial Diagnostics and Fluid Dynamics (CDIF), Polytechnic University of Catalonia (UPC), Av. Diagonal, 647 ETSEIB, 08028 Barcelona, Spain; E-Mails:

david.valentin@mf.upc.edu (D.V.); egusquiza@mf.upc.edu (E.E.); valero@mf.upc.edu (C.V.)

2 International University of Catalonia, C\Immaculada 22, 08017 Barcelona, Spain;

E-Mail: pere.alavedra@uic.cat

* Author to whom correspondence should be addressed; E-Mail: alfredo.guardo-zabaleta@upc.edu; Tel.: +34-934015943; Fax: +34-934015812.

Received: 5 June 2013; in revised form: 18 September 2013 / Accepted: 18 September 2013 /

Published: 30 September 2013

\begin{abstract}
Free convection is the most often used method in order to reduce solar load gains on a building with double glazed façades (DGFs). However, depending on the climate factors, the thermal performance of a DGF may not be satisfactory and extra energy costs are required to obtain suitable comfort conditions inside the building. Forced ventilation systems are a feasible alternative to improve the thermal performance of a DGF in Mediterranean climates where large solar gains are a permanent condition throughout the year. In this paper the feasibility of using diverse forced ventilation methods in DGF is evaluated. In addition, an economical comparison between different mechanical ventilation systems was performed in order to demonstrate the viability of DGF forced ventilation. Moreover, an environmental study was carried out to prove the positive energetic balance on cooling loads between free and forced convection in DGF for Mediterranean climates. For this investigation, a CFD model was used to simulate the thermal conditions in a DGF for the different ventilation systems. Results obtained for heat flux, temperature and reductions in solar load gains were analyzed and applied for the economic and environmental research.
\end{abstract}

Keywords: double glazed façades (DGF); Coandă nozzle; forced convection; building thermal performance; cooling load savings; environmental impact 


\section{Introduction}

Double glazed façades (DGF) are one newest technical options to increase the comfort and efficiency in office buildings. DGF are appropriate when buildings are subject to great external noise and wind loads or when passive solar heating is used. Moreover, DGF have a special aesthetics of their own and this fact can be exploited architecturally to great advantage, especially in singular buildings creating iconic landmarks in the city skyline.

Implementation of DGF in buildings has been an object of broad study and application in recent years. DGF may be classified in several types, according to the type of construction, the type of the cavity, the tightness of both skins, the materials used, etc. (see e.g., [1-3]). The most common classification concerns the channel height. Some authors [4] classify DGFs in building as high DFGs, when the air cavity has the building's total height, or storey-high DGFs, when the air channel is divided into air cavities with the height of each storey.

Sometimes, depending on climate factors, the thermal performance of a DGF is not satisfactory and extra energy costs are necessary in order to obtain suitable conditions in the inner space of the building. This fact is particularly true in Mediterranean climates, where large solar gains are a permanent condition during the whole year, even during wintertime. DGF can act as a greenhouse, allowing the ultraviolet and visible solar radiation to enter the building while keeping the infrared energy re-radiated by the building structure trapped. A comparison between traditional (without glass) and simple glazed façades against double glazed façades is shown in Figure 1. DGFs improve the thermal performance of buildings with a simple glazed façade, but they increase the interior heat flux compared to classical façades. Gratia and de Herde [5] studied a building with and without DGF under several external climatic conditions and they demonstrated that the use of a DGF decreases the heating loads but increases the cooling loads.

Figure 1. Example of interior heat fluxes for different types of façades.

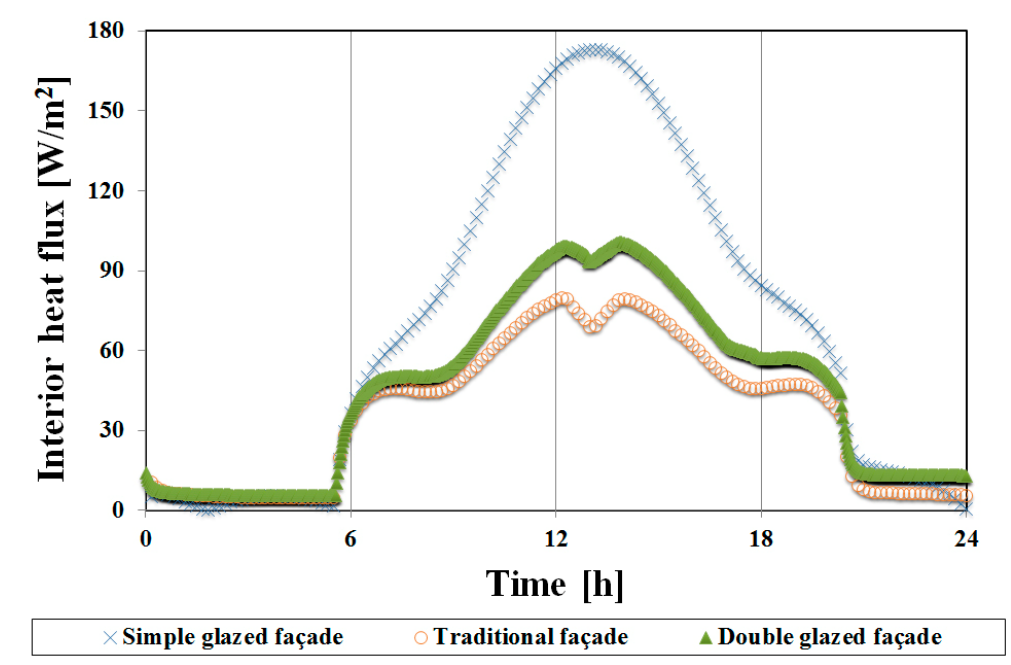

Several strategies are useful to alleviate the poor thermal performance of DGF, such as natural ventilation by means of technical openings between floors and chimneys at the top, or forced convection ventilation systems in diverse geometrical configurations. Free convection methods are based in thermal gradients and flow buoyancy effects and they are specially recommended for 
locations with small solar gains in winter [1]. Forced convection ventilation system implies the use of mechanical ventilation to force the air flow through the DGF cavity [1]. Often, hybrid ventilation systems are also implemented in buildings using free and forced convection methods to improve its performance [6]. Recent studies showed that forced convection methods present a reduction of solar load gains in summertime in front of natural ventilation [7] and a higher percentage in wintertime [8].

In order to study the behavior of a DGF, computational fluid dynamics (CFD) have been used and validated by several research groups. Manz [9] and Sedlák et al. [10] presented a comparison between a complete simulation work of forced and free convection cases in a DGF and experimental measurements. The good agreement with the experimental results demonstrated the viability of CFD to study the thermal performance of a DGF. Guardo et al. [7,11,12] performed simulations of a storey-high DGF in Mediterranean climates and they evaluate the influence of construction an operation parameters of a DGF, as well as the optimal DGF forced ventilation methods. Several ventilation methods were analyzed, such as vertical ventilation, horizontal homogeneous ventilation, upper and lower crossed lateral ventilation and swirling flow ventilation. Vertical ventilation requires 10 times the air flow rate to obtain the same reduction of solar load gain that the lateral ventilation systems (see e.g., [11]). Upper crossed lateral ventilation was the most interesting option because it reduces about $25 \%$ of solar load gain with a low flow injection. Examples of DGF buildings implementing horizontal ventilation, such as Galleries Lafayette Building in Berlin, can be found in the literature [3].

Fans are the most conventional and widespread system used to implement forced convection ventilation in DGF, but nowadays there are new technical possibilities in order to carry out the mechanical ventilation of the air cavity of a DGF. Valentín et al. [13] performed studies introducing Coandă nozzles as a feasible alternative to the forced convection ventilation systems. The installation of fans in a façade has several disadvantages, but the most important drawback is the cost of maintenance. Fans have rotating components and bearings which wear away after certain operating time and they have to be replaced from time to time. Due these requirements, an accessible space has to be enabled in the building, or even mobile scaffoldings could be required in order to perform maintenance tasks. Coandă nozzles do not require any maintenance because they have no rotating components, therefore their implementation in a façade may result in important economic savings. In this paper, the feasibility of implement forced ventilation systems with Coandă nozzles in a DGF is evaluated and an economic comparison between this system and regular fans is carried out.

The environmental impact of DGFs has been an object of broad study in recent years. A DGF without free or forced convection ventilation systems can act as a greenhouse, hence the thermal comfort inside the building could be unsatisfactory and extra cooling loads may be required in summertime. A complete analysis of the energy consumption in cooling loads for different types of DGF ventilation systems was performed by Hien et al. [14]. Forced convection presented an important reduction in cooling loads in front of natural ventilation, therefore considerable energy and environmental impact savings could be obtained. Haase et al. [15] confirmed these conclusions carrying out a comparison between experimental results and simulations works for several operating conditions in different buildings. Saelens et al. [16] compared different operation strategies in order to improve the energy performance of a DGF using hybrid ventilation systems, such as controlling the inlet airflow rate and the recovery of air returning from the multiple-skin facades. Other control strategies were proposed by Park and Augenbroe [17], including optimization of operating costs of the 
mechanical ventilation system implemented in a double skin façade. Jaroš et al. [18] demonstrated that large glazing areas in a DGF may also require large heating and cooling loads during the year, and mechanical ventilation is needed in order to implement a sustainable building. Furthermore, other authors (Stec et al. [19] and Cianfrini et al. [20]) studied mechanical ventilation methods implemented with the HVAC system and they demonstrated an improvement of the thermal behavior of a DGF. Moreover, DGFs could reduce electric energy costs through the use of natural solar light and they may significantly decrease the external and internal ambient noise [21].

The aim of this investigation is to evaluate the economic and environmental impact produced by a DGF forced ventilation system based in Coandă nozzles [13]. Numerical data used in this study have been obtained by this research group [7,11-13] by means of CFD. The DGF geometry and mesh model were situated in Barcelona and upper crossed lateral ventilation (horizontal ventilation) were defined as the optimal mechanical ventilation system. Figure 2 shows an example of the integration of the mechanical ventilation system in the studied DGF. In this paper, an economic analysis has been carried out through the comparison between two different mechanical ventilation systems and an environmental impact research has been performed using free and forced convection simulation results.

Figure 2. Example of the integration of mechanical ventilation systems in DGF.

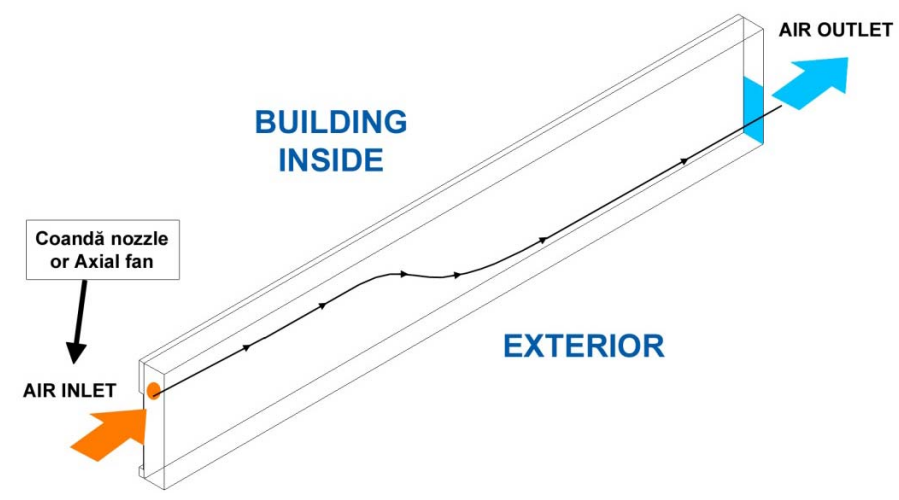

\section{Previous Works}

The most conventional system used to implement this type of ventilation in DGF is based on fans. However, the installation of fans in a DGF has several drawbacks:

- Fans need an electrical grid connection, so they have to meet strict fire hazard regulations;

- A solid support has to be built-up in the lateral side of the façade in order to install them;

- Fans have rotating components, such as motor or bearings, which require maintenance;

- They also generate vibration and noise.

The cost of the electrical system required by fans can be considerable, especially due to the safety requirements imposed by the government. The support structure also increases the overall cost of installation because it needs to ensure that vibrations produced during the operation of fans are not transmitted through the whole structure of the building. Noise generated by the impeller and flow turbulence can also propagated in the rooms located away the fan and generate uncomfortable effects.

Maintenance is definitely an important drawback of fan ventilation systems. Fans units have a limited life because the rotating components wear away after a certain operating time. For instance, 
roller bearings are prone to fatigue problems and they must be replaced from time to time. Therefore, an accessible space has to be enabled in the building in order to perform maintenance tasks and replacement of the units if necessary. Mobile scaffoldings are also usually needed to repair the fan units from the building exterior. These facts increase the operating costs of a DGF and sometimes the economic inversion may not be viable.

Flow regulation can also be another disadvantage when using fans on a DGF. The air flow rate required to ventilate the façade has to be regulated depending on weather conditions and solar radiation levels. Fans can regulate the flow rate using a speed variator or a variable blade pitch system, but both increase the cost of the equipment and add up more maintenance requirements.

Coandă nozzles were studied in previous works [13] as a feasible alternative for forced ventilation in DGF. They present many advantages when compared with fans (see Figure 3):

Figure 3. Isometric view of the Coandă nozzle studied by Valentín et al. [13].

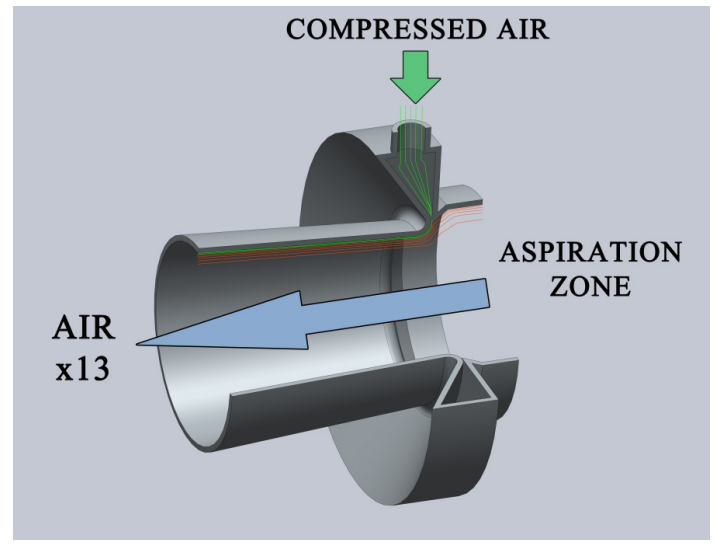

- They do not need maintenance because they have no moving parts;

- They do not generate vibration;

- They are light and compact structures;

- They implement a flow regulation system adjusting only the pressure of the injected air;

- Coandă nozzles do not need any electrical connections, so they do not have to comply with any safety requirements;

- Coandă nozzles generate low level noise and its origin is exclusively aerodynamic.

Fans generate noise from sources of three different origins: mechanical, electrical and aerodynamic. Like all rotating machinery a fan consists in a rotating shaft with an electrical motor and an impeller supported by bearings. During operation mechanical vibrations are generated by rotating forces (unbalance) and by roller bearings. These vibrations are propagated through all the structure generating noise. This is inherent to all rotating machinery and can be reduced but not avoided. In electrical motors vibrations are generated by the electromagnetic fields and the levels depend on the type and accuracy of construction of the motor. With normal degradation of bearing and motor noise is prone to increase with time. From the fluid dynamic point of view, noise is generated by the rotating blades (spatially non-uniform) what gives the tonal noise, by turbulence in the wakes of the blades and by the turbulence of the main flow. 
Compared with a fan, in Coandă nozzles there are no moving parts (there are neither rotating components nor a motor). In this case, noise is only generated by flow turbulence. Because flow velocities are low for this application and similar in a fan or in a nozzle application, noise should be lower in the latter. This hypothesis can be demonstrated with experimental and analytical studies performed by Karabasov [22].

The fluid dynamics and thermal behavior of Coandă nozzles in a DGF forced ventilation system were previously studied [13] by means of CFD. Guardo et al. [7,11] studied the thermal response of the same DGF, but in this case, with a free and forced conventional ventilation system. It was assumed that the DGF analyzed was located in Barcelona, Spain $\left(41.23^{\circ} \mathrm{N}, 2.11^{\circ} \mathrm{E}\right)$. The DGF proportions were set to $0.8 \mathrm{~m} \times 4 \mathrm{~m}$ for the flow channel and $24 \mathrm{~m}$ of depth according to the legal regulations issued by the Spanish government [23]. The complete DGF geometry comprises (from outside to inside) an external glazing, an air gap, an internal double glazing (52.5\% of the internal façade area) and an internal wall (47.5\% of the internal façade area). Air can flow between the gap through two openings at the lateral ends of the façade. A detailed description of the façade configuration and material properties can be found in [13].

Solar radiation data (global and diffuse) and climatic data (for outside temperature) were taken from public databases available from Catalonia's governmental energy agency [24]. Time-dependency of the outside temperatures were fitted into a sixth degree polynomial $\left(r^{2}>0.9\right)$ and introduced to the CFD solver via user defined functions (for further insight see e.g., [11,13]). P1 radiation model together with a solar radiation calculator were used for the dynamic estimation of solar loads over the façade. All the aforementioned data was set to match the data used in previous work developed by this research group $[11,13]$. The results obtained for heat flux and reductions in solar loads gains in both works have been used in this paper for the economic and environmental research.

The influence of the façade orientation was also studied by this research group [13] and obtained results show that south orientation is more influenced by solar radiation than others. South façade requires a $12 \mathrm{~h}$ operation for the DGF forced ventilation system, while east or west façades only need to be ventilated for approximately $6 \mathrm{~h}$ a day (Figure 4) corresponding to the hours of direct solar radiation incidence. Manz and Frank [25] presented results of the influence of the façade orientation which agree with results obtained by this research group.

Figure 4. Results of heat flux inside the building obtained by Valentín et al. [13]. (a) South façade orientation; (b) East façade orientation.

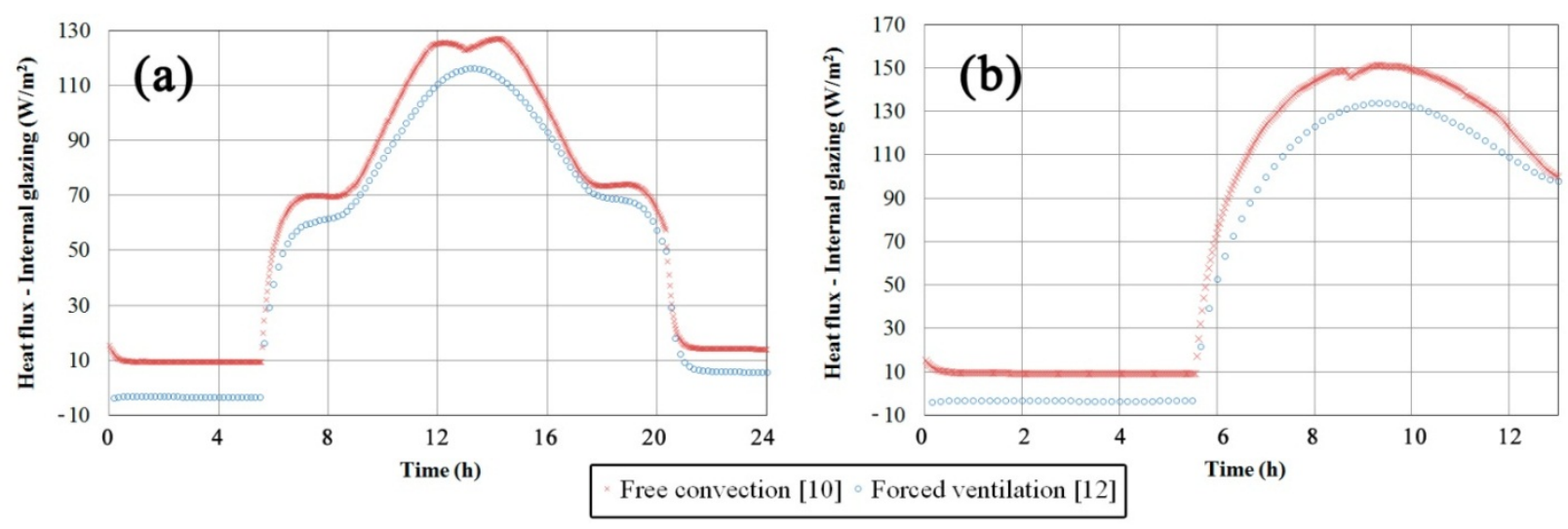




\section{Economic Study}

An economic study has been performed comparing forced ventilation systems using Coandă nozzles and fans. In order to compare both systems, different types of costs have been considered. Initial investment, operation and maintenance costs are the most important charges for these ventilation systems. Table 1 shows a comparison between both studied ventilation systems for each type of costs and main cost description is also presented. For this economical study, a three storey DGF is considered and maximum ventilation flow rate studied in previous works [13] is used $\left(2.77 \mathrm{~m}^{3} / \mathrm{s}\right)$.

Table 1. Comparison between Coandă nozzles and fans main costs.

\begin{tabular}{cll}
\hline \multicolumn{1}{c}{ Cost } & \multicolumn{1}{c}{ Coandă nozzles } & \multicolumn{1}{c}{ Fans } \\
\hline \multirow{3}{*}{ Initial investment } & -Compressor or blower & -Machinery \\
& -Nozzle manufacturing & -Electric grid \\
& -Compressed air installation & -Firefighting safeguards \\
\hline Operating costs & -Compressor or blower energy consumption & -Fans energy consumption \\
\hline \multirow{2}{*}{ Maintenance costs } & -Compressor or blower maintenance & -Fans maintenance \\
& -Compressed air grid maintenance & -Electric grid maintenance \\
\hline
\end{tabular}

\subsection{Initial Investment}

Cost estimation methods have been used in order to determine economic values of the Coandă nozzle and fan ventilation systems investment. The Lang, Guthrie and Williams methods [26-29] were used for estimating the capital cost of both studied ventilation systems. These methods have been used for a long time for estimating costs for plants and equipment and they offer only about $20 \%$ of estimation error [29]. The Lang factor was introduced in 1947 as a valid method for estimating the total installation cost for plants and equipment [26]. In the sixties, Guthrie expanded the concept introducing different factors for different types of process equipment, including blowers, fans and compressors $[27,28]$. Williams' method or "the six-tenths rule" was used in order to adapt the standard machinery costs to the appropriate cost of equipment with other similar characteristics [29]. In order to update the costs obtained by estimation methods, the Chemical Engineering Cost Plant Index (CEPCI) was applied. Equipment costs were obtained in 1984 databases, therefore the 2013-1984 CEPCI ratio was used [30,31].

In the case of Coandă nozzles, a $30 \mathrm{~kW}$ blower is required in order to implement the complete compressed air installation meeting the air flow and pressure drop requirements (see Table 2). The blower can be installed at the top of the building or in a technical level, in an accessible location near the façade. Manufacturing cost of the Coandă nozzles was evaluated using injection molding process estimators given by specialized manufacturers. For the ventilation system using fans, three wall fans were used for each DGF storey with a volumetric air flow rate of $2.77 \mathrm{~m}^{3} / \mathrm{s}$ each one. The comparison between the cost obtained for both ventilation systems after estimation costs methods were used is showed in Figure 5. 
Table 2. Air flow, pressure and power requirements of the air compressed installation.

\begin{tabular}{|c|c|c|c|c|}
\hline $\begin{array}{c}\text { Air flow } \\
\text { requirements of a } \\
\text { Coandă nozzle } \\
\left(\mathbf{m}^{3} / \mathbf{s}\right) \\
\end{array}$ & $\begin{array}{c}\text { Pressure } \\
\text { requirements in the } \\
\text { Coandă nozzles' inlet } \\
(\mathrm{kPa})\end{array}$ & $\begin{array}{c}\text { Air flow requirements } \\
\text { of the whole air } \\
\text { compressed installation } \\
\left(\mathrm{m}^{3} / \mathrm{s}\right)\end{array}$ & $\begin{array}{c}\text { Blower } \\
\text { pressure } \\
\text { (kPa) }\end{array}$ & $\begin{array}{c}\text { Blower } \\
\text { power } \\
(\mathrm{kW})\end{array}$ \\
\hline 0.04 & 1.38 & 0.13 & 2.50 & 1 \\
\hline 0.09 & 4.87 & 0.26 & 9.50 & 4 \\
\hline 0.12 & 11.56 & 0.37 & 21.50 & 8 \\
\hline 0.15 & 23.78 & 0.44 & 39.50 & 20 \\
\hline 0.16 & 41.65 & 0.48 & 60.00 & 30 \\
\hline
\end{tabular}

Figure 5. Comparison between investment costs of Coandă nozzle ventilation systems and fan ventilation systems.

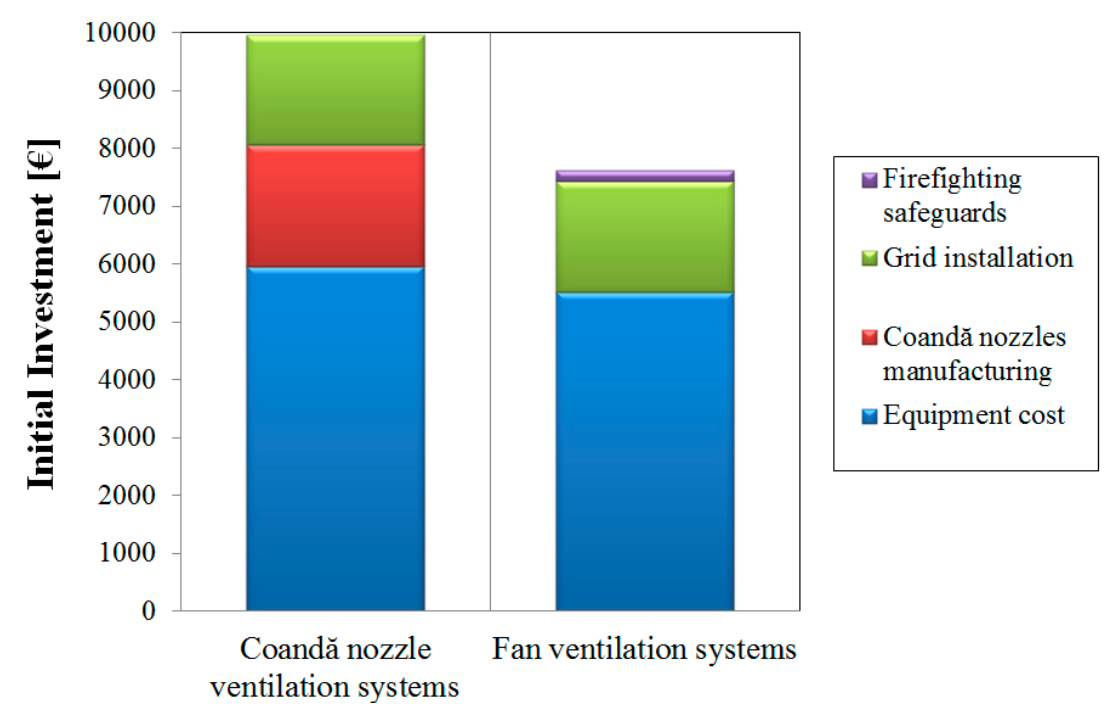

\subsection{Operating Costs}

In order to implement a flow regulation system using Coandă nozzles, an analysis of reduction in solar load gains comparing different mass flow rates tested by Valentín et al. [13] was performed. Mass flow inlet law for Coandă nozzles was estimated comparing the reduction in solar load gains using the maximum mass flow rate injected, against the reduction in solar load gains with the minimum mass flow rate. Results obtained for mass flow rate and power consumption laws are showed in Figure 6 for both façade orientations studied.

In the case of fans, $980 \mathrm{~W}$ of electrical power and $283 \mathrm{~Pa}$ of Specific Fan Power (SFP) units were selected due to volumetric flow rate requirements. No regulation system was implemented in the fans, so they will be running at maximum power during all day operation. Figure 6 also shows the fans' power consumption for south and east façades orientations.

Energy consumption was estimated integrating the power curve showed in Figure 6 during all day operation. Average sunshine hours per year in Barcelona were estimated using public databases available from Catalonia's government energy agency [24]. These data together with average irradiance values were considered for estimate the number of operating hours that the ventilation system will have to work. Calculations have determined 1725 operation hours per year, therefore total 
year energy consumption can be estimated applying irradiance reduction factors corresponding to winter time. Figure 7 shows the operating cost comparison between both ventilation systems studied for south and east façades orientations.

Figure 6. Mass flow rate and energy consumption of both ventilation systems compared.

(a) South façade orientation; (b) East façade orientation.
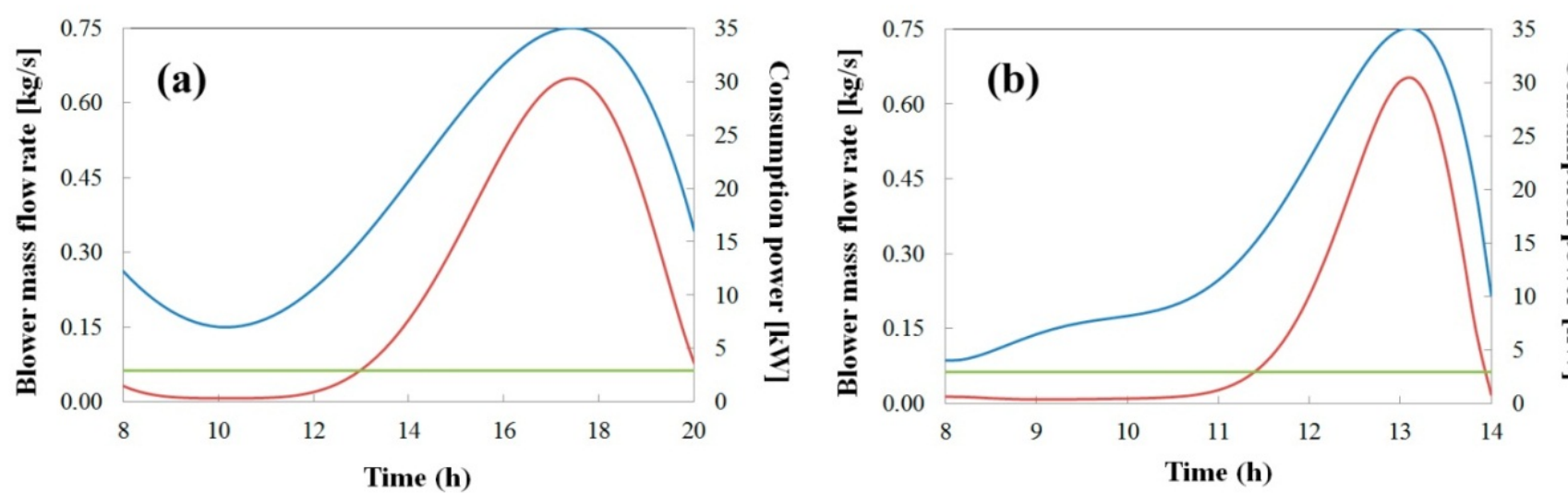

Figure 7. Operating costs of Coandă nozzle ventilation system in comparison with fan ventilation system for different façades orientations.

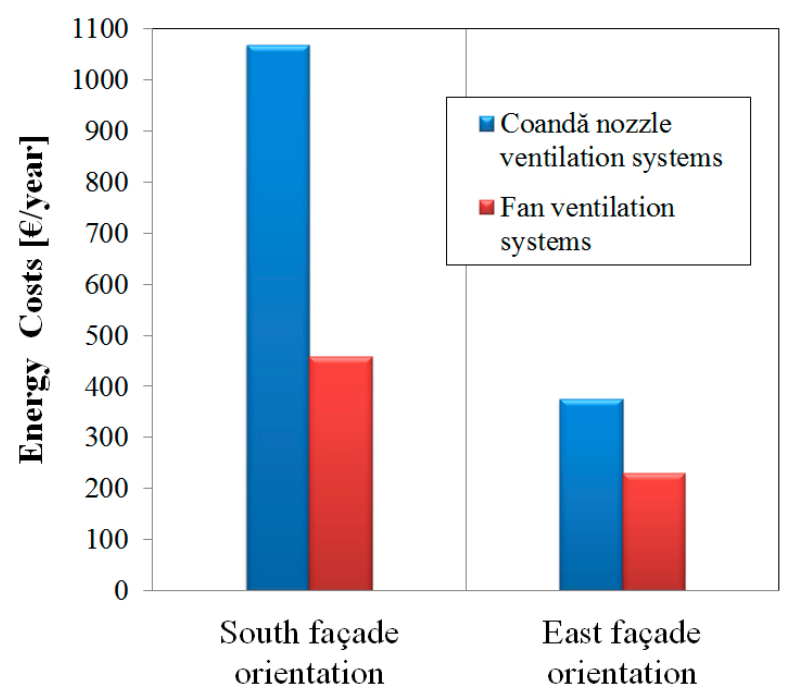

\subsection{Maintenance Costs}

Maintenance costs are the great advantage of Coandă nozzle ventilation systems when compared with conventional fan ventilation systems. Coandă nozzle ventilation systems only require blower maintenance tasks as an attributable cost, while fans often need to be repaired or replaced because their mobile parts wear away after a certain time in operation. Therefore, the cost of blower maintenance tasks was estimated by operation hours, as recommended by manufacturers [32-34]. Common maintenance tasks for compressors are visual inspections, oil changes, shaft balance and bearings replacement. Visual inspection and oil change are the most usual jobs and they can be carried out by regular building 
maintenance staff, whereas shaft balance and bearing replacement need qualified manpower to be performed. These tasks have been considered in Coandă nozzles ventilation system (Figure 8).

Figure 8. Comparison between maintenance costs of both ventilation systems studied.

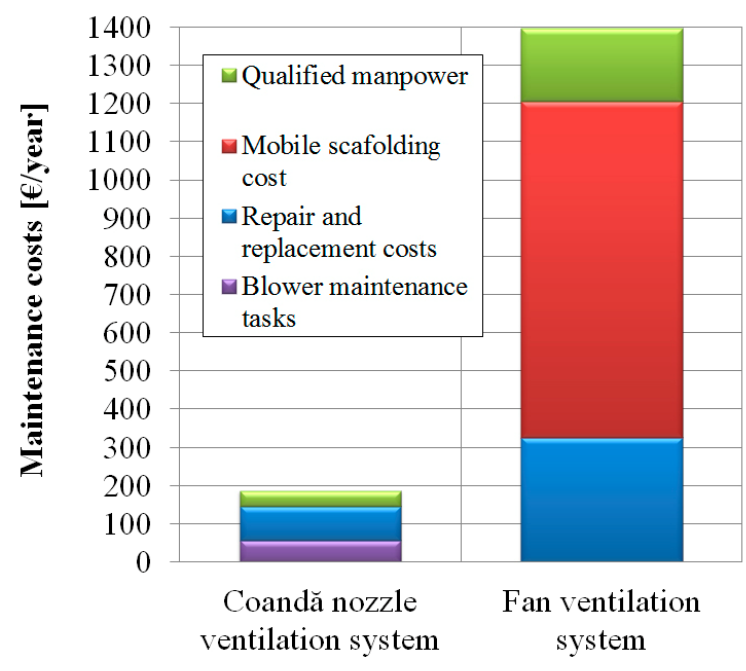

However, in a fan ventilation system, the cost of the machinery access and qualified manpower also has to be considered. Public price databases were used in order to estimate maintenance costs of fan ventilation system implemented in DGF. Rent, shipment and assembly of scaffoldings were considered, as well as eight labor hours per year. Comparison between detailed maintenance costs can be observed in Figure 8.

\subsection{Total Costs Comparison}

The use of Coandă nozzle ventilation system leads to a reduction in total attributable costs in comparison with fan ventilation system (see Figure 9). Initial investment cost is larger for Coandă nozzles than for fans, therefore a payback analysis using net present value (NPV) has to be performed in order to demonstrate the economic feasibility of implementing Coandă nozzles as a DGF forced ventilation system. An investment horizon of 25 years was considered for the study using the economic saving between both ventilation systems as a reference income. Future evolution of energy price was considered according to predictions studied by the European Commission "Eurostat" [35]. A constant inflation rate of $2 \%$ and a rate of interest of $4 \%$ were used according to country's specifications. Industrial taxations were also considered for this evaluation. Figure 10a shows the percentage of economic profit on initial investment obtained every year and the prediction of future evolution of energy price, while Figure $10 \mathrm{~b}$ presents the yearly aggregated percentage. In this picture, a 5 years payback can be observed (100\% of accumulated percentage) for the south façade orientation and a 3 years payback in the case of east façade. After 25 years, 3-7 times the initial investment can be saved using Coandă nozzle ventilation systems. 
Figure 9. Total attributable costs of both ventilation systems for different façade orientations.

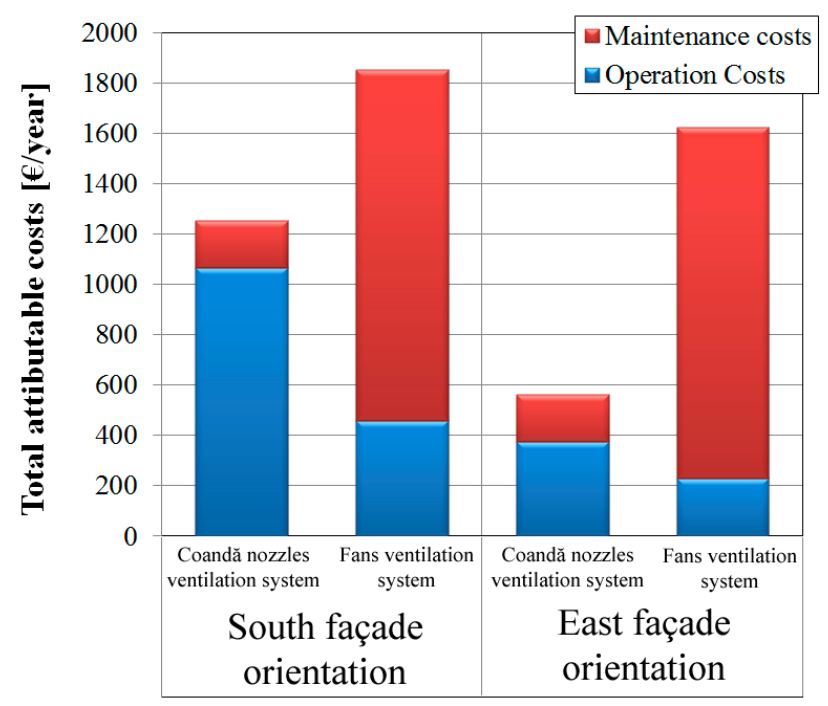

Figure 10. Percentage of profit on the initial investment during a 25 years horizon. (a) Yearly economic profit and evolution of energy price; (b) Aggregated economic profit.
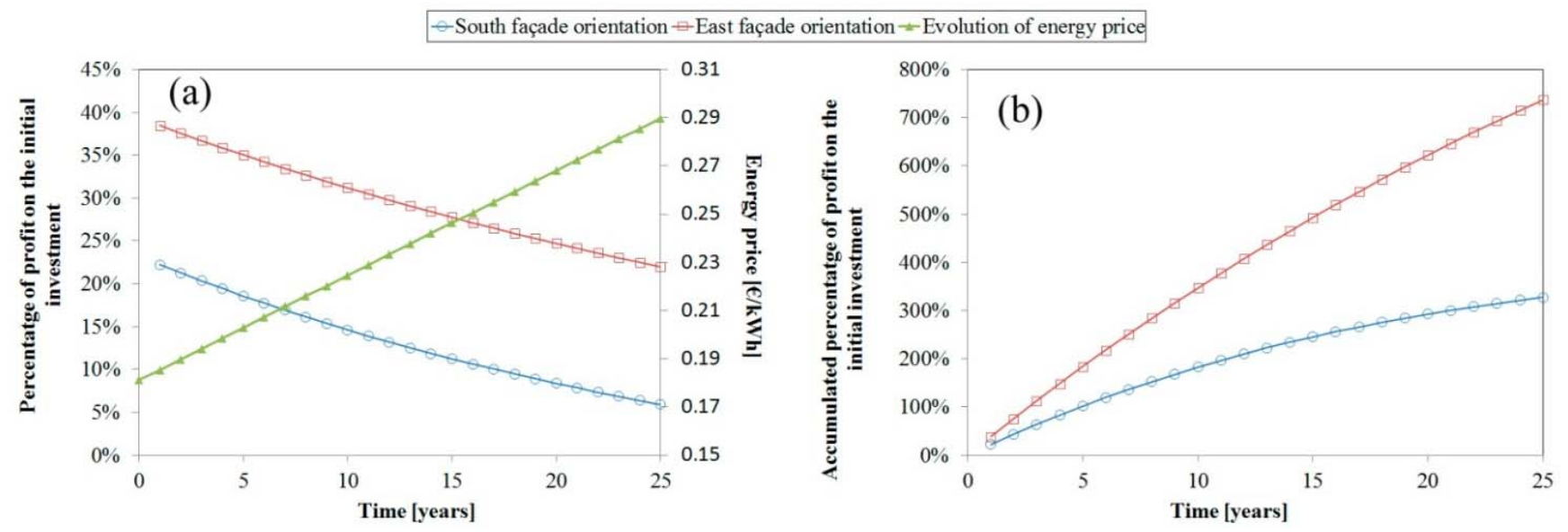

It should be noted that ventilation systems using fans could be more economic changing the studied distribution system based on axial wall fans by other type of disposition, such as ductwork coupled to a general industrial fan on the roof. This fact reduces the maintenance cost of fans and it can make economically feasible this alternative. It could be interesting to study this option in future contributions.

\section{Environmental Impact Estimation}

\subsection{Life Cycle Assessment}

In order to compare the environmental impact of Coandă nozzles ventilation system against standard forced ventilation systems with fans, a simple analysis of their Life Cycle Assessment (LCA) has been carried out. LCA studies the energy used during the whole cycle of any open system, from the production of every part of the system to the disposal of them [36,37]. A graphic description of an example of LCA is shown in Figure 11. The LCA is a complex method widely used for estimate 
the environmental impact of several systems, therefore, the two main parts of the LCA, energy consumption of production and use, were analyzed for both proposed ventilation systems.

Figure 11. Environmental impact evaluated using a standard Life Cycle Assessment (LCA).

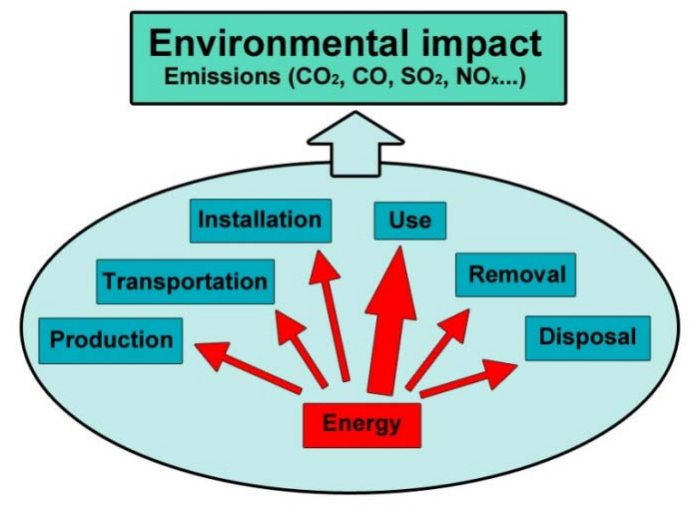

\subsubsection{Material Production and Manufacturing}

Nyman and Simonson [36] analyzed the environmental impact produced by the energy consumption of the material production and manufacturing. This method is based on separating the total weight of every material used in the production of the system in order to attribute standard values of energy consumption and greenhouse gas emissions. Recyclability of materials is included in the method, therefore the energy recovered during the recycling period is also taken in consideration. In this case, materials and weights used for both studied ventilation systems are shown in Table 3.

Table 3. Material weight description for both studied ventilation systems.

\begin{tabular}{cc|cc}
\hline Fans ventilation system & Weight (kg/unit) & Coandă nozzles ventilation system & Weight (kg/unit) \\
\hline Fans & - & Coandă nozzles & - \\
Steel and sheet metal & 18 & Plastic & 32 \\
Copper & 2 & Blower or compressor & - \\
Aluminum & 5 & Steel and sheet metal & 110 \\
Plastic & 1 & Copper & 4 \\
- & - & Aluminum & 10 \\
- & - & Plastic & 10 \\
- & - & Natural rubber & 1 \\
\hline
\end{tabular}

It was assumed that the fans were replaced every 10 years of operation according to manufacturers' recommendations. 25 years life cycle was defined for the calculations. Coandă nozzles and the blower do not need to be replaced during this life cycle due to their low operating hours and also manufacturer's instructions. The energy required to produce both ventilation systems and its components are presented in Table 4. These values include the transportation of materials. The energy required to produce each material was estimated using the same conversion factor as in the literature [36]. The primary energy efficiency and the energy distribution were extracted from the Spanish Diversification and Energy Saving Institute [38]. Emissions associated with energy generation for both systems are also estimated using public data [38] (see Figure 12). 
Table 4. Primary energy (MJ) used in the production of both studied ventilation systems over the 25 year life cycle.

\begin{tabular}{c|ccc|c|ccc|c}
\hline \multirow{2}{*}{ Material } & \multicolumn{4}{|c|}{ Fans (MJ/life cycle) } & \multicolumn{4}{c}{ Coandă nozzles (MJ/life cycle) } \\
\cline { 2 - 9 } & Renewable & Non-Renewable & Embodied & Total & Renewable & Non-Renewable & Embodied & Total \\
\hline Steel and sheet metal & 270.00 & 2392.20 & 141.75 & 2803.95 & 220.00 & 1949.20 & 115.50 & 2284.70 \\
Copper & 61.35 & 666.30 & 0 & 727.65 & 16.36 & 177.68 & 0 & 194.04 \\
Aluminum & 87.00 & 1674.00 & 1071.38 & 2832.38 & 23.20 & 446.40 & 285.70 & 755.30 \\
Plastic & 102.53 & 719.10 & 0 & 821.63 & 1457.22 & $10,220.81$ & 0.00 & $11,678.03$ \\
Natural rubber & - & - & - & - & 1.00 & 36.30 & 56.11 & 93.41 \\
\hline Total & 520.88 & 5451.60 & 1213.13 & 7185.60 & 1717.78 & $12,830.39$ & 457.31 & $15,005.48$ \\
\hline
\end{tabular}

Figure 12. Total emissions from the production of materials over the 25 year life cycle.

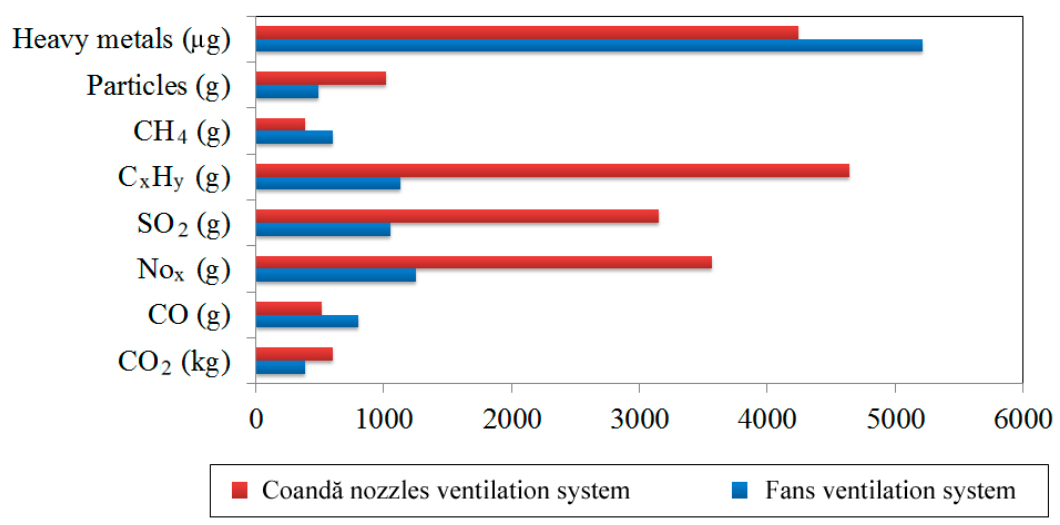

\subsubsection{Operating Energy Consumption}

Using results obtained for both ventilation systems of energy consumption per year, an estimation of consumed energy for the full life cycle can be calculated. Figure 13 shows a comparison between the energy consumption for production and manufacturing and the necessary energy for the operation of Coandă nozzles and fans ventilation systems over 25 years life cycle. It can be observed that the consumed energy for production and manufacturing of both systems represents only about a $5 \%$ of the total operating energy consumption, therefore the emissions will also be proportional to these results.

Figure 13. Total energy consumption over the 25 year life cycle.

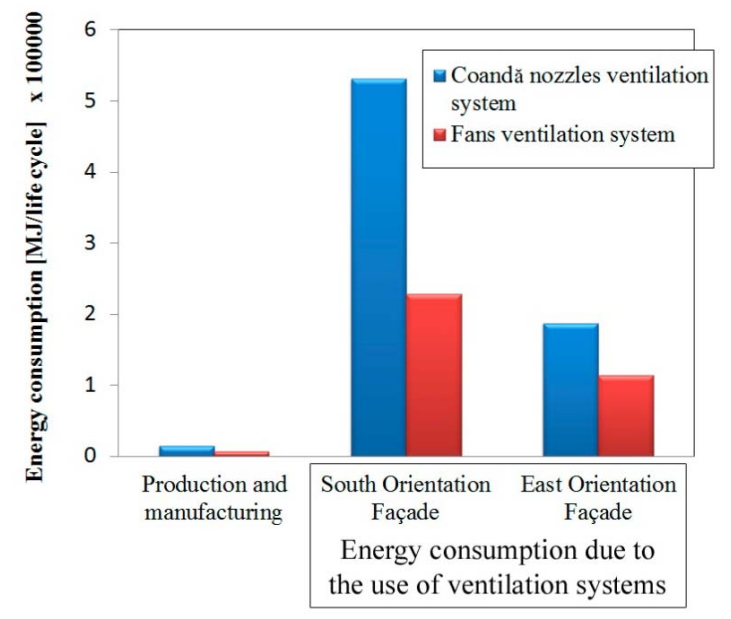




\subsection{Energy Savings Produced through the Use of Forced Ventilation}

In Mediterranean climates, a DGF can act as a greenhouse, accumulating heat in the inner space between outside and inside glasses. Therefore, cooling loads needed to keep the interior comfort have to be larger than in a building with a traditional façade. Results obtained by Valentín et al. [13] showed high temperatures in the internal glass at the midday, over $45{ }^{\circ} \mathrm{C}$ in the case of free convection ventilation. With the implementation of a Coandă nozzle ventilation system, the temperature at the internal glass can be reduced by $5{ }^{\circ} \mathrm{C}$, so the required cooling loads decrease resulting in energy savings.

For this environmental impact study, a comparison between free convection and Coandă nozzle ventilation system was carried out for a three storey DGF. Twelve offices as shown in Figure 14 were considered in order to calculate required cooling loads. Internal glass temperature obtained in previous works is showed in Figure 15 for south façade orientation. This temperature and radiation heat fluxes were obtained through fully transient numerical simulations [13], and the obtained values were used to estimate energy savings in cooling loads, also presented in Figure 15. The time step for CFD simulations was set to $600 \mathrm{~s}$ in the case of forced ventilation and $120 \mathrm{~s}$ in natural convection cases [13].

Figure 14. Dimensions and characteristics of the considered office.

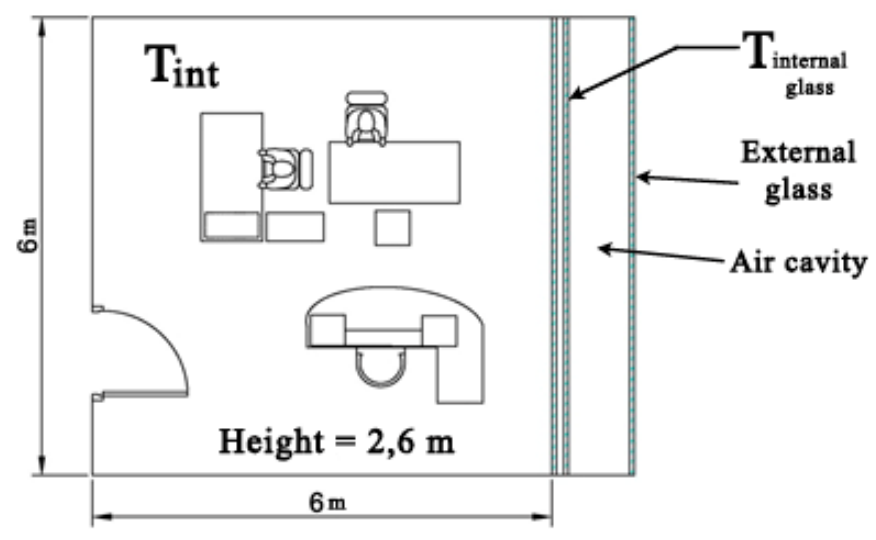

Figure 15. Internal glass temperature for free and forced convection ventilation systems and energy savings in cooling loads during a day operation.

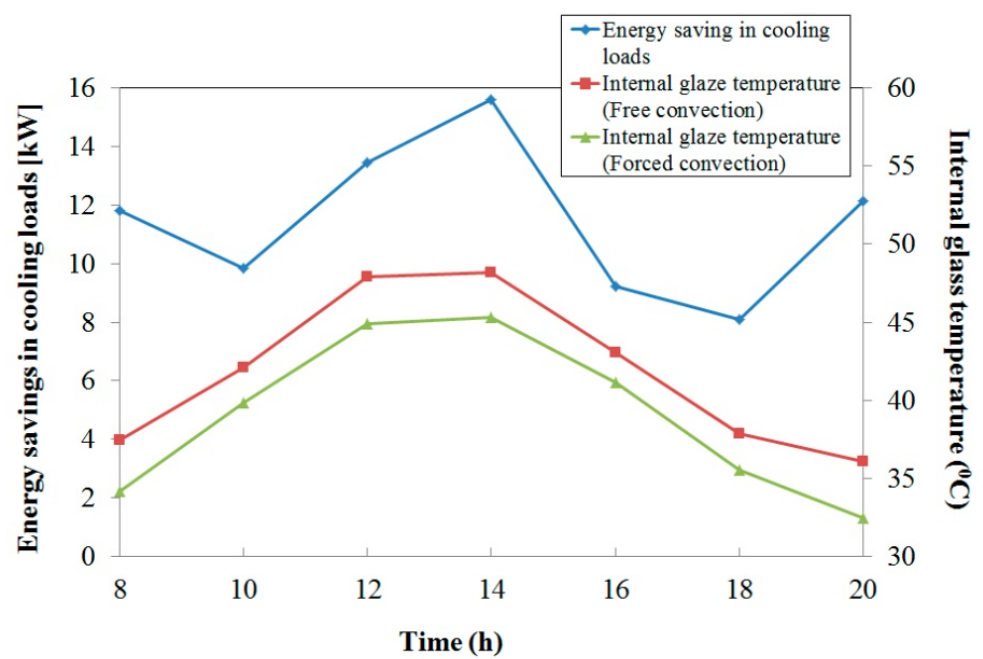


The method used to determine cooling loads is based on the theoretical calculation of sensible and latent cooling loads. In order to estimate sensible cooling loads, radiation and transmission through interior and exterior windows, doors and walls were considered. Heat generated due to ventilation or infiltration air, people occupying the room or electric lighting was also included in the estimation of the sensible load. The estimation of latent cooling loads only includes the heat generation terms aforementioned. The total cooling load of each office is the sum of these terms. A safety factor of $20 \%$ to ensure the perfect refrigeration of the building was used. The interior comfort temperature was set to $25{ }^{\circ} \mathrm{C}$, while the interior comfort humidity was set to $10 \mathrm{~g}_{\text {water }} / \mathrm{kg}_{\text {air }}$. In order to estimate the electrical power comsumption required to guarantee the cooling loads, a coefficient of performance (COP) of 2.4 was used. For further information about the applied method, see e.g., [39,40].

Figure 16 shows the energy savings in cooling loads and the energy ventilation consumption obtained when free and force convection ventilation systems are used. An important energy saving can be observed using Coandă nozzles in comparison to forced ventilation system. This reduction in energy consumption involves also a reduction in polluting gases emitted in energy generation, such as $\mathrm{CO}_{2}$. The conversion factor used to determine $\mathrm{CO}_{2}$ emissions was obtained from the Spanish Diversification and Energy savings Institute [38]. Considering 800 operating hours during the summer according to statistics for sunlight hours in Barcelona [23], a reduction in energy consumption of about $2 \mathrm{MWh}\left(0.66 \mathrm{tCO}_{2}\right)$ for the south façade orientation and $9 \mathrm{MWh}\left(3 \mathrm{tCO}_{2}\right)$ for the east façade orientation should be expected when using a Coandă nozzle forced ventilation system instead of a free convection ventilation system.

Figure 16. Energy savings using forced ventilation systems in DGF for south and east façade orientations.

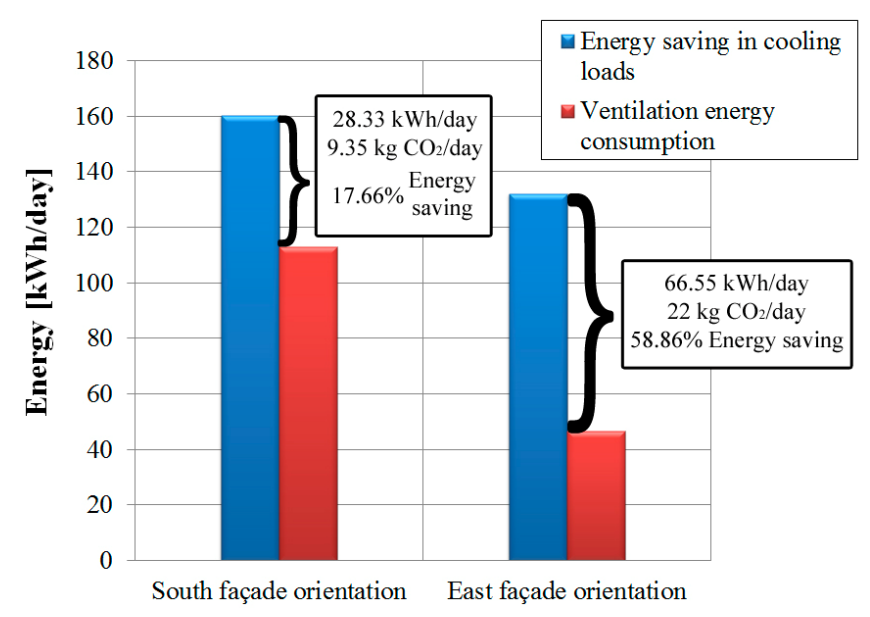

\section{Conclusions}

Coandă nozzles prove to be a feasible alternative to conventional fans for forced horizontal ventilation in double glazed façades. These nozzles are light, compact structures with no moving parts (therefore they are maintenance free), they do not generate noise or vibrations, and do not require any electrical grid connections, which can reduce the final cost when building one of these façades. Previous work shows that Coandă nozzles ventilation systems improve the thermal performance of DGF when compared with other ventilation configurations such as vertical ventilation [13]. The 
obtained results demonstrated that high flow velocities favored the flow mixing within the air cavity of the DGF, enhancing the convective heat transfer phenomenon within the flow stream and the solid surfaces. Air flow through Coandă nozzles could be regulated varying the inlet nozzle pressure, therefore a simple regulation system could be easily implemented.

An economic study was performed in order to study the viability of the implementation of Coandă nozzles in a DGF forced horizontal ventilation system. Initial investment was estimated by means of cost estimation methods [25-30] and obtained results showed that investing in Coandă nozzles is more expensive than conventional systems such as fans. Operation costs were also estimated through manufacturer recommendations and public price databases. Coandă nozzle ventilation systems presented a higher operational cost when compared with fan ventilation systems.

Maintenance cost is a great advantage for Coandă nozzles, as the only attributable maintenance costs for this ventilation system come from the blower. However, fans require repair and replacement tasks, the use of mobile scaffoldings and qualified manpower, so their total maintenance cost is high-priced.

It should be noted that ventilation systems using fans could be more economic by changing the studied distribution system based on axial wall fans by other type of disposition, such as ductwork coupled to a general industrial fan on the roof. This fact reduces the maintenance cost of fans and it can make economically feasible this alternative. It could be interesting to study this option in future contributions.

The sum of the total costs shows a better economic performance for Coandă nozzles. 3-5 years payback of the original investment was estimated for a Coandă nozzle ventilation system if compared with the economic performance of a fan ventilation system. In a 25 -year horizon, a $300 \%-700 \%$ return of investment can be expected using Coandă nozzles as forced ventilation system in DGF.

The 25-year Life Cycle Assessment (LCA) performed shows that energy consumption in production and manufacturing of machinery is about a $5 \%$ of the total operating consumed energy. This LCA was performed considering the weight of each material of the used machinery in order to estimate the consumption of energy in the material manufacturing process. Comparing the environmental impact caused by both ventilation systems, Coandă nozzles require more energy in their manufacture and also produce higher amounts of emissions of polluting gases during the manufacturing processes.

The environmental impact estimation carried out comparing free convection and Coandă nozzle ventilation systems shows important energy savings for Coandă nozzles. Temperature reached in the internal glass using a free convection ventilation system was elevated (as much as $45^{\circ} \mathrm{C}$ ), therefore, as a result of DGF air cavity ventilation, this temperature decreased and lower cooling loads are required. The balance between ventilation energy and cooling loads savings was positive. About 2 to $9 \mathrm{MWh}$ can be saved depending on the façade location during the summer, which involves a reduction of 0.6 to $3 \mathrm{tCO}_{2}$ in pollutant emissions associated with energy generation. A fan ventilation system consumes less energy during operation than Coandă nozzles, therefore these values of energy saving could be larger when horizontal ventilation is implemented with fans.

\section{Acknowledgments}

The authors acknowledge the economic support received from Grupo JG Consultora de Proyectos S.A. and Universitat Internacional de Catalunya for developing this work. Fundings from the Spanish Ministry of Economy and Competitivity (Grant No. DPI2012-36264) is also appreciated. 


\section{Conflicts of Interest}

The authors declare no conflict of interest.

\section{References}

1. Faggembauu, D. Heat Transfer and Fluid-Dynamics in Double and Single Skin Façades. Ph.D. Thesis, Universitat Politècnica de Catalunya, Barcelona, Spain, 2006.

2. Loncour, X.; Deyener, A.; Blasco, M.; Flamant, G.; Wouters, P. Ventilated Double Façades. Classification \& Illustration of Façade Concepts; Belgian Building Research Institute: Limelette, Belgium, 2004.

3. Poirazis, H. Double Skin Façades for Office Buildings, Literature Review. Division of Energy and Building Design; Report EBD-R-04/3; Department of Construction and Architecture, Lund Institute of Technology: Lund, Sweden, 2004.

4. Compagno, A. Intelligent Glass Façades; Birkhäuser: Berlin, German, 1995.

5. Gratia, E.; de Herde, A. Optimal operation of a south double-skin facade. Energy Build. 2004, 36, 41-60.

6. Hensen, J.; Bartak, M.; Frantisek, D. Modeling and simulation of a double-skin façade system. ASHRAE Trans. 2002, 108, 1251-1259.

7. Guardo, A.; Coussirat, M.; Egusquiza, E.; Alavedra, P.; Castilla, R. A CFD approach to evaluate the influence of construction and operation parameters on the performance of active transparent façades in Mediterranean climates. Energy Build. 2009, 41, 534-542.

8. Baldinelli, G. Double skin façades for warm climate regions: Analysis of a solution with an integrated movable shading system. Build. Environ. 2009, 44, 1107-1118.

9. Manz, H. Total solar energy transmittance of glass double façades with free convection. Energy Build. 2004, 36, 127-136.

10. Sedlák, J.; Mráček, P. Simulation of the Double Facade in the Brno Metropolitan Library. In Proceedings of the Dynamic Analysis, Simulation and Testing Applied to the Energy and Environmental Performance of Buildings, DYNASTEE, Athens, Greece, 12-14 October 2005.

11. Guardo, A.; Coussirat, M.; Valero, C.; Egusquiza, E.; Alavedra, P. CFD assessment of the performance of lateral ventilation in Double Glazed Façades in Mediterranean climates. Energy Build. 2011, 43, 2539-2547.

12. Coussirat, M.; Guardo, A.; Jou, E.; Egusquiza, E.; Cuerva, E.; Alavedra, P. Performance and influence of numerical sub-models on the CFD simulation of free and forced convection in double-glazed ventilated façades. Energy Build. 2008, 40, 1781-1789.

13. Valentín, D.; Guardo, A.; Egusquiza, E.; Valero, C.; Alavedra, P. Use of Coandă nozzles for double glazed façades forced ventilation. Energy Build. 2013, 62, 605-614.

14. Hien, W.N.; Liping, W.; Chandra, A.N.; Pandey, A.R.; Xiaolin, W. Effects of double glazed facade on energy consumption, thermal comfort and condensation for a typical office building in Singapore. Energy Build. 2005, 37, 563-572.

15. Haase, M.; Wong, F. Double-skin facades for Hong Kong. Surv. Built Environ. 2007, 18, 17-32. 
16. Saelens, D.; Roels, S.; Hens, H. Strategies to improve the energy performance of multiple-skin facades. Build. Environ. 2008, 43, 638-650.

17. Park, C.; Augenbroe, G. Local vs. integrated control strategies for double-skin systems. Autom. Constr. 2013, 30, 50-56.

18. Jaroš, M.; Mohelníková, J.; Plšek, D. Glazed Facades and Their Influence on Indoor Climate Buildings. In Proceedings of the CESB 07 Prague Conference, Prague, Czech Republic, 24-26 September 2007; Session M3C: Energy 1.

19. Stec, W.J.; van Paassen, A.H.C. Symbiosis of the double skin façade with the HVAC system. Energy Build. 2005, 37, 461-469.

20. Cianfrini, C.; Corcione, M.; Habib, E.; Quintino, A. Energy performance of a lightweight opaque ventilated façade integrated with the HVAC system using saturated exhaust indoor air. Energy Build. 2012, 50, 26-34.

21. Streicher, W. BESTFAÇADE: Best Practice for Double Skin Façades, WP 1 Report "State of the Art”; Institute of Thermal Engineering, Graz University of Technology: Graz, Austria, 2005.

22. Karabasov, S.A. Understanding jet noise. Philos. Trans. R. Soc. 2010, 368, 3593-3608.

23. Código Técnico de la edificación (in Spanish), Real decreto 314/2066 del 17 de marzo. Sección S1 5, Apartado 2. Gobierno de España. Available online: http://www.codigotecnico.org/cte/export/ sites/default/web/galerias/archivos/DB_SI_19feb2010.pdf (accessed on 5 June 2013).

24. Mitjà, A. Atlas de Radiació solar a Catalunya (in Catalan); Institut Català d'Energia: Barcelona, Spain, 2001.

25. Manz, H.; Frank, Th. Thermal simulation of buildings with double-skin façades. Energy Build. 2005, 37, 1114-1121.

26. Lang, H.J. Cost relationships in preliminary cost estimation. Chem. Eng. 1947, 54, 117-121.

27. Guthrie, K.M. Process Plant Estimating Evaluation and Control; Craftsman Book Co.: Los Angeles, CA, USA, 1974.

28. Page, J.S. Conceptual Cost Estimating Manual; Gulf Publishing Company: Houston, TX, USA, 1984.

29. Perry, R.H.; Green, D.W. Perry's Chemical Engineers' Handbook, 8th ed.; McGraw-Hill: New York, NY, USA, 2007.

30. Vatavuk, W.M. Updating the CE plant cost index. Chem. Eng. 2002, 109, 62-70.

31. Lozowski, D. Economic indicators. Chem. Eng. 2013, 120, 63-64.

32. Aerzen Ibérica (in Spanish). Available online: http://www.aerzen.es/Productos/Soplantes-Aerzende-desplazamiento-positivo (accessed on 25 November 2012).

33. Grupo Genser (in Spanish). Available online: http://www.grupogenser.com/PDF/SOPLANTESKAESER/Cat\%C3\%A1logo\%20Soplante\%20Serie\%20Compact.pdf (accessed on 25 November 2012).

34. Pedro Gil S.L. Available online: http://www.pedrogil.com/docs/1-MANUAL\%20INSTR.\%20PG30-F1\%20ENG.pdf (accessed on 25 November 2012).

35. European Commission "Eurostat". Available online: http://epp.eurostat.ec.europa.eu/ statistics_explained/index.php/Energy_price_statistics (accessed on 30 July 2013).

36. Nyman, M.; Simonson, C.J. Life cycle assessment of residential ventilation units in a cold climate. Build. Environ. 2005, 40, 15-27. 
37. Ortiz-Rodríguez, O.; Castells, F.; Sonnemann, G. Life cycle assessment of two dwellings: One in Spain, a developed country, and one in Colombia, a country under development. Sci. Total Environ. 2010, 408, 2435-2443.

38. IDAE Instituto para la Diversificación y Ahorro de la Energía (in Spanish). Available online: http://www.idae.es/index.php/mod.documentos/mem.descarga?file=/documentos_Factores_ConveC onve_Energia_y_CO2_2011_0a9cb734.pdf (accessed on 29 July 2013).

39. Miranda, A.L. Técnicas de Climatización (in Spanish); Marcombo, S.A.: Barcelona, Spain; 2010; pp. 47-57.

40. American Society of Heating, Refrigerating and Air-Conditioning Engineers, Inc (ASHRAE). ASHRAE Handbook Fundamentals; ASHRAE: Atlanta, GA, USA, 2009; Chapters 17-18.

(C) 2013 by the authors; licensee MDPI, Basel, Switzerland. This article is an open access article distributed under the terms and conditions of the Creative Commons Attribution license (http://creativecommons.org/licenses/by/3.0/). 